\title{
Astakoures - Astakouroi
}

\section{J. Desanges}

\section{OpenEdition}

Journals

Édition électronique

URL : http://journals.openedition.org/encyclopedieberbere/1203

DOI : 10.4000/encyclopedieberbere.1203

ISSN : 2262-7197

\section{Éditeur}

Peeters Publishers

\section{Édition imprimée}

Date de publication : 1 janvier 1989

Pagination : 1004

ISBN : 2-85744-443-5

ISSN : 1015-7344

\section{Référence électronique}

J. Desanges, « Astakoures - Astakouroi », Encyclopédie berbère [En ligne], 7 | 1989, document A302, mis en ligne le 01 décembre 2012, consulté le 12 octobre 2020. URL : http://journals.openedition.org/ encyclopedieberbere/1203; DOI : https://doi.org/10.4000/encyclopedieberbere.1203

Ce document a été généré automatiquement le 12 octobre 2020

(c) Tous droits réservés 


\section{Astakoures - Astakouroi}

\section{J. Desanges}

1 Les Astakoures sont mentionnés par Ptolémée (IV, 3, 6, éd. C. Müller, p. 641) « sous » les Nigitimi, lesquels bordent le littoral entre les Kinithii (Cinithi), groupés autour de Gigthis (Bou Ghara), et les Lotophages*, considérés à tort par le Géographe alexandrin comme des riverains du fleuve Kinups (Cinyps), actuel oued Oukirré (ibid., p. 638), mais en réalité liés à l'île de Djerba. Il ne semble donc pas qu'il faille les situer trop loin au sud du golfe de Gabès. Comme le suggère Chr. Courtois (Les Vandales et l'Afrique, Paris, 1955, p. 348, ne 7, A 3), ils sont probablement à assimiler aux Astrices de Corippus.

2 Des Astakouri sont, par ailleurs, signalés par Ptolémée (IV, 6, 6, p. 748), mais en Libye Intérieure et non plus en Afrique. Ils étaient voisins des Gorges garamantiques (vallée de l'ouadi el-Agial, cf. Ch. Daniels, The Garamantes of Southern Libya, Stoughton, 1970, pl. 2 et 3). Il semble toutefois difficile de séparer les Astakouri des Astakoures. De la même façon, les Dolopes, mentionnés par Ptolémée immédiatement avant les Astakouri, dans la Libye Intérieure, ont été déjà nommés par le Géographe en Afrique, non loin des Lotophages. Peut-être faut-il supposer que les mêmes tribus ont été signalées par lui à chaque extrémité d'un axe de nomadisation unissant le Fezzan ou le Grand Erg oriental au Golfe de Gabès.

INDEX

Mots-clés : Antiquité, Tribu 